\title{
Antiquity versus Modernity: Aspects of Lifestyles and Life-conditions ${ }^{1}$
}

\author{
Kofi Ackah \\ Associate Professor, Department of Philosophy and Classics, \\ University of Ghana, Legon
}

\begin{abstract}
Biology and ecology set optimal limits to our potential for development and significant deviations from these limits threaten our well-being and existence. Yet there seems to be little, if any, concern, for those significant deviations that are atavistic and are reinforced by or are generated from Western industrial modernity, which most Third World countries have adopted as their favoured approach to national development. This paper focuses on nine of the areas in which these deviations occur. The measure of deviation, explicitly or implicitly made, is a select set of lifestyles and life-conditions in modernity and antiquity. The emphasis in this paper on ecologically or biologically efficient lifestyles and lifeconditions in antiquity is not a recommendation to return to the ways of antiquity; it is to highlight the principles and values of wellness embedded in those ways in order to provoke further discussions and to imply either that creative adaptations of those lifestyles and life-conditions are desirable or that policy interventions may be required to address deviations from them.
\end{abstract}

Keywords: antiquity, modernity, life-conditions, biology, ecology

In this paper I shall use 'modernity' and 'antiquity' in a predominantly cultural rather than chronological sense. I shall mean by 'modernity' lifestyles and life-conditions based on Western science and technology, and by 'antiquity' the 'pre-industrial' or, in certain contexts, 'pre-scientific' ways of life. As characterised, 'modernity' and 'antiquity' are very broad categories: each abstracts from innumerable local, regional, class and diachronic variations in lifestyles and life-conditions.

Modernity has a lot of good things to offer. At least, it promotes a culture capable of reproducing itself at higher levels and largely able to meet the ever-growing needs of large masses of people. Yet, almost without exception, human ways of doing things, however well thought-out, have unintended side effects. Thus, it is common knowledge

1 An earlier version of this paper was presented at the [then] annual Faculty of Arts Colloquium held on the 14th and 15th of April, 2010 at the Great Hall, University of Ghana. I am grateful to the anonymous reviewer for useful suggestions. 
that aspects of modernity have either reinforced or produced significant deviations from the life-conditions and lifestyles that are optimal for human flourishing and for the sustainability of our ecology. Western research and public discourse have for decades highlighted these side effects ${ }^{2}$ and Western nation-states do, generally, make efforts to address same. Further, because of global concern about the issues, numerous resolutions of the UN and other international bodies - on food, climate, environment, povertyreduction, education, etc. - have raised awareness about them and/or are attempting to address them. Yet, most developing societies appear to be adopting modernity indiscriminately - as there is little evidence of critical awareness of, or policy direction against, the said side effects.

In what follows, I address nine of these side effects, for two reasons: to provoke further discussions on them and to suggest that such side effects could be avoided or at least limited either by policy controls and/or by a creative adaptation of aspects of life and thought in antiquity, as characterised.

\section{The 'Scientific' Attitude to Nature}

Substantial changes in nature do affect our biological systems; but how much we are thus affected depends also on our general attitude to nature. Western science, practised on a strict logical elimination of value from facts $^{3}$, reflects the utilitarian attitude to nature that is wasteful in terms of excess production and consumption. In antiquity, human beings generally saw themselves as part of, rather than as separate from, the rest of nature. Groves, forests, meadows, water bodies and other vital sections of the ecology were invested with sacredness and sanctity and this investment resonated with our existential needs. Generally, such an attitude guaranteed biodiversity and the ecological balance that could secure the long-term survival and wellbeing of our species. Admittedly, this religious attitude to nature was 'pre-scientific.' Nor was it necessary or sufficient to save the biosphere: even in early antiquity, some societies for whom nature was sacred destroyed their natural habitation. ${ }^{4}$ Thus it seemed rational to welcome the European alternative, which evolved in the $17^{\text {th }}$ and $18^{\text {th }}$ centuries $A D$, when Bacon, Galileo, Descartes, Newton and others contributed various more empirically informed

2 The literature is huge. To mention just three early ones, see Thomas 1956, Passmore 1980 and Boyden 1987.

3 Until concern with ecological sustainability became global recently, occasional theoretical protests in the past against the fact-value distinction failed to gain any significant impact. One example is Julian Huxley (1947), who argued to the effect that what is ethical in human behaviour favours our biological evolution.

4 For example, in his Critias (111b-c), written in the fourth century BC, Plato makes this ecological observation of Attica: 'There are remaining only the bones of the wasted body, as they may be called...all the richer and softer parts of the soil having fallen away, and the mere skeleton of the land being left. But in the primitive state of the country, its mountains were high hills covered with soil, and the plains...were full of rich earth, and there was abundance of wood in the mountains.' In the same context, Plato tells us how 'sacred memorials' remain where once flowed rivers and streams. 
perspectives on nature generally regarded as scientific - an attitude whose effect makes nature an object, filtered out of value, which the human subject can and has to manipulate to yield results that would satisfy human needs and wants.

To be sure, the scientific attitude has deepened our empirical knowledge of nature; but this is arguably knowledge without understanding (Max-Neef, 2009, p. 18), without the resonance of deep meaning, because an essential part of us - our feeling, intuition, imagination is consciously withheld or divorced from the reality we claim to know. Once it is unscientific to love, revere and respect nature, the alternative has been to see nature in purely utilitarian terms ${ }^{5}$ - with disastrous impacts on our ecology and biology. The apparent exception is ecological science, called by some 'the subversive science.' This has evolved to be an oasis in the landscape of the scientific temper-in a sense a mock return to the pantheistic, pre-scientific past. By insisting that what violates the natural harmony must be condemned and what enhances it must be endorsed, its holistic sensibility is a radical deviation from traditional science (Roszak, 1976, pp. 463469).

We might start addressing this problem of the materialistic objectification of nature by appreciating the active, phenomenological constructivism of the mind or the complex, multi-layered structure of nature of which we are a part and the possibilities of many truths (religious, scientific, etc.) on a single subject, whether or not these truths cohere. Such an appreciation should be complemented by a linguistic shift away from the one dimensional vision of, and dependence on, the language, tools and methodologies of science to more open and pluralistic approaches, able to recognise competing and complementing pathways, such as between science and cultural traditions that promote our biological, ecological and social-psychological well-being.

\section{The Sense of Economic Growth}

Another problematic heritage from modernity is the sense of economic growth, which clearly implies the utilitarian attitude to nature earlier mentioned. Based on the use of machines and capitalism, modernity sustains itself by the accumulation of more wealth and goods for the satisfaction of an ever-expanding array of material needs and wants, for the further growth of the economy, for increasing the range of consumer choices and for pursuing higher and higher standards of living. Because mainstream economics claims to be value-free, the assumption that continuously increasing the range of consumer choices (consumerism) is desirable has rarely been seriously questioned. Indeed, we now live in a world in which it would be suicidal for a politician seeking high office to canvass

5 That value-judgments, aesthetic or ethical, can be unpacked as perceptions of how a set of empirical facts conduce to our biological or socialpsychological functionality has been forcefully argued. See for example, Durant, 1952, pp. 186-203 on 'What is Beauty?' and Baier, 1958, pp. 826 on 'Value Judgments.' 
moderation in material consumption. Yet, as has been noted by many development economists, this materialistic conception of economic growth is inconsistent with the long-term ecological sustainability of human society (Leiss, 1978, p.23).

With the emergence of Development Economics (DE) in the 1950s and 1960s, there was much optimism that this was a new pathway to promote true development and overcome poverty in the Third World. But as the hoped-for goals were not fully realised, the language and practice of DE have been superseded by neo-liberal ideology, such as Hayek (1944) exemplifies. This ideology is essentially blind to the possibility of market failure, regards all state interventions as anathematic, presumes that the market is an infallible guide to all economic strategies and prescribes a developmental model based on absolute subservience to the interests of capital, unfettered trade and total freedom for private enterprise-in all situations and circumstances. ${ }^{6}$

The free-market dogma is backed by powerful international financial institutions, hegemonistic Western states and right-wing think-tanks. The following tenets seem to constitute its attractiveness: (a) the assumption of a free individual operating in free markets; (b) the efficiency of the market mechanism in delivering the greatest amount of resources at the minimum cost, all things being equal; (c) the fairness of the market system, as it rewards individuals according to their contribution-the price others are willing to pay for their services being a measure of their social value; and (d) the scientific strength in the precision of its theoretical tools and in its objectivity and universality (Gilles, 2009, p. 48, pp.63-65).

Arguably, the enduring side effects of the free-market dogma degrade its theoretical attractiveness. These include the rapacious exploitation of natural resources, especially non-renewable ones; global warming; and significant disturbances of the lifesupporting processes of the biosphere. Besides, the dogma 'creates and aggravates terrible inequities and disparities, ${ }^{7}$ tolerates high levels of chronic unemployment and deprivation, and destroys social cohesion' (Bidwai, 2009, pp. 36-37).

These consequences, one could argue, amount to significant deviations from the largely needs-based economies of antiquity. Yet neo-liberalism continues to shape the policies and management of many Third World countries. This is evidenced by the proliferation of stock exchange markets, the wholesale liberalisation of most Third World economies, reinforced by a deceptively objective and morally neutral international trade

\footnotetext{
6 Very much against the grain of historical reality —insofar as the development of First and Second World countries have required some degree of state protection of nascent industries; the promotion, at the state's expense, of education, especially technology; domestic trade; and the equitable distribution of assets and income. See, for example, Bidwai, 2009.

7 So, for example, the National Health Insurance Scheme in Ghana is useful intervention, because its effective implementation would guarantee basic health services to all. But this welfare goal has been frustrated by political and management problems.
} 
principle, the Law of Comparative Advantage ${ }^{8}$ and fuelled by global markets dominated by natural resource extractions. ${ }^{9}$ It is common knowledge that the control of these markets has been slipping from the hands of elected national governments into those of transnational corporations, regional trading blocs and global institutions, such as the IMF, World Bank and the World Trade Organisation.

Perhaps one way to address the problem is, as Gilles argues, to teach pluralist Economics curricula, which would comprise various divergent theoretical orientations and competing approaches, for example, Neo-Classical, Keynesian, Marxist, the feminist critique, along with, one must add, critical sensitivity to traditional values and institutions. These varied perspectives must include both 'positive' and 'normative' aspects of economics, such as the relationship between markets and greed or materialism; between markets and power relationships; between efficiency and equity; and between resource exploitation and its impact on the ecology, livelihood and culture.

\section{Egalitarianism}

Societies have polarised into haves and have-nots since the dawn of civilisation. ${ }^{10} \mathrm{On}$ the other hand, modernity promises and has modestly delivered an advancement in standards of living. Cell phones count among the latest in the instruments of modern civilisation with a global reach serving the communication and economic needs of rich and poor alike. However, the global improvement in standards of living has done little to close the gap between the rich and the poor. For example, the market distribution of wealth in industrialised societies has generally given rise to large differences in material wealth and income that deviate significantly from the relative egalitarian structures of the largely needs-based economies of the much simpler societies of antiquity (cf. Harrison, 1981, pp. 405-418). Income distribution in the USA published in 2004 shows that the bottom $90 \%$ of citizens earn an average income of US\$ 30,374 annually and the top $10 \%$

8 The 'Law of Comparative Advantage' claims that every nation stands to gain if it specialises in those goods it can produce more cheaply. However, this morally neutral principle is deceptive, given the contribution to global competitive pricing of well-known Western government subsidies to certain national industrial productions.

9 Writing in 1981 (pp. 337-345) Paul Harrison noted that Third World exports are roughly two-thirds primary products and imports are roughly two thirds of manufactured goods. This structure of third world economies does not appear to have changed much in the last thirty years. See, for example, Ghana Economy Profile, 2013 at www.indexmundi.com/ghana/economy/profile.html (accessed 8/6/13 at 6 pm), in which Ghana's export commodities are listed as oil, gold, cocoa, timber, bauxite, aluminium, manganese ore, diamonds, and horticultural products—all primary products. Roughly the same economic structure is repeated across most of the Third World.

10 Every textbook on the history of Greek antiquity carries the story of Solon's 6th century BC social and political reforms in Athens, which sought to reduce the explosive tension between the rich few, who also controlled power, and the poor masses, who were excluded from power. In Roman antiquity, too, significantly similar economic and social conditions led to the protracted Conflict of the Orders-between the patricians and the plebeians. 
an average US\$269, 658 (including capital gains). ${ }^{11}$ An overview of income inequalities in the Organisation for Cooperation and Economic Development (OECD) countries, according to a 2011 Report, shows that, on average, the income share held by the top $10 \%$ of the population, before taxes and transfers, is $45.7 \% .^{12}$

The organisation Global Finance provides country by country data from the World Bank development/poverty indicators on wealth distribution and income inequality, ${ }^{13}$ based on GINI coefficients. These measure the extent to which the distribution of income or consumption expenditure among individual households within a country deviates from a perfectly equal distribution. The data for the first decade of the 2000's show that economic inequality within countries has been widening over the past ten years or more. According to the 2006 data on Ghana, the percentage of the population living on less than US\$ 2 a day is $51.84 \%$, while the income share held by $10 \%$ of the population is $32.75 \%$. In 2010 the percentage of Nigerians living on less than US\$ 2 a day was $84.49 \% .^{14}$ Roughly the same pattern of wealth distribution in Ghana can be found in most developing capitalist economies. In real terms, the messenger's salary is barely of subsistent value, while his top executive gets several multiples of it. Harrison's observation in 1981 is still applicable: 'these are inequalities not just of material possessions, but in lives, in minds, in flesh and blood, in wellbeing and in confidence in the world' (Harrison, 1981, p. 410).

One justification of the free-market system is that the inequalities it generates constitute an incentive for people to work harder, invest more, and so on, which will lead to greater wealth for all. And the evidence is obvious: Western industrialised countries are wealthier and have generally higher standards of living across the social spectrum than in poorer countries. The Scandinavian countries, in particular, show that it is possible to attain high per capita income while ensuring a minimum level of inequality. And there is also strong evidence in these countries that state interventions, particularly in the production of public goods such as health and education, promote both equality and efficiency of the workforce and production. ${ }^{15}$ But this is cold comfort for the increasing millions who continue to live in grinding poverty, especially in most of the Third World. One factor that severely interferes with the enjoyment of life is the chronic feeling of

11 Wealth distribution data, 2004, from the Federal Reserve Board's Survey of Consumer Finances. Retrieved from

http://www.wealthandwant.com/issues/income/income_distribution.html.Accessed 6/8/2013 at 8.24 pm.

12 Retrieved from http://www.gfmag.com/tools/global-database/economic-data/11944-wealth-distribution-income-

inequality.html\#axzz2VpfVWCEB.Accessed 6/8/2013 at $840 \mathrm{pm}$.

13 Wealth distribution differs from income inequality: the former refers to ownership of assets in a given society; the latter refers to differences in income.

14 Retrieved from http://www.gfmag.com/tools/global-database/economic-data/11944-wealth-distribution-income-inequality.

15 Pace Jackson Andrew, 'Why We Don't Have to Choose between Social Justice and Economic Growth: The Myth of the Equity/Efficiency Tradeoff,'Canadian Council on Social Development Report, quoted by Gilles, 2009, p. 74. 
deprivation, which occurs when individuals are aware that others in the neighbourhood have much higher material standards of living than they have. Such an experience, if accompanied by difficulties in occupational or social mobility, can lead to angst, mental and physical ill-health and patterns of interpersonal behaviour that may interfere with the order and stability of society.

An emerging by-product of the interface between the widening economic inequalities and science is the growing empowerment of the well-to-do to use enhancement medicine or drugs to advance their functionality, including their intelligence, life-span or range of emotions. If the trend continues, a pill for developing multilingual competence may soon cease to be science-fiction. These possibilities have given rise to the belief called ableism - the acceptance of the idea of the transhumanisation of the human species functioning beyond today's species-typical capacities. The danger is that enhanced performances may in future set a new norm. One consequence would be that the non-enhanced majority of people regarded today as 'normal,' but who may not be able to afford enhancement medicine or drugs, are likely to be regarded as disabled and inferior tomorrow (Wolbring, 2009, p. 141). Such 'disableism,' likely to involve discrimination, oppression or abuse, would have serious implications for pluralism, social order and the survival of the human species. ${ }^{16}$

It seems, then, that we need to create alternative or complementary systems of values and economic development models that, while allowing differentiation and providing incentives for enterprise, retain a strong view of relative egalitarianism consistent with economic and social efficiency.

\section{Formal Education}

Modernity continues to require a shift from general education to subject specialisation, especially in scientific, technical, vocational, business and other professional studies in response to industrial needs. Thus, the general content of education has increasingly become utilitarian, with growing emphasis on science and technology. Admittedly, specialisation is necessary for in-depth study of subject-matter, whatever this may be. But as different subjects represent different aspects of reality, it is unfortunate that little effort is devoted to the multi- or inter-disciplinary integration that will improve understanding of the organic interrelationships between these aspects of reality.

One of the consequences of the extreme emphasis on specialisation in formal education is the fact that the human products of such education have extraordinarily different world-views and pictures of the same reality-so much so that effective

\footnotetext{
16 The World Transhumanist Association is an international non-profit organization. It believes in the development and access to new technologies that enable everyone to enjoy better minds, better bodies and better lives. But it strongly advocates the ethical use of technology to expand human capacities.
} 
communication between them on serious societal topics can be very difficult, sometimes impossible. Thus some religious leaders, who are otherwise highly educated formally, appear to be completely insensitive to polluting residential neighbourhoods with deafening amplitude of church music (often through the instrumentality of imported audio systems). Similarly, graduates in radically different disciplines are unlikely to agree in detail as to the problems and options facing modern society. Thus universities which prescribe certain general capacity-building courses for all beginning students and encourage flexibility in cross-subject choices at higher levels seem to be doing the right thing.

Industrialisation tends to undermine the importance of general education by demanding the vocationalisation and by promoting a utilitarian conception, of higher education. The practice of the free-market dogma intensifies the utilitarian allure by promising a materially comfortable life, through the cultivation and practice of what is pleasing or satisfying to the atomic individual. Its sense of 'fairness' or 'justice' appeals to the supposed objectivity and level playing field of the invisible hand of market forces, thereby encouraging the belief that significant inequities among a population is a normal reflection of the individual's efforts. By referring to the individual's 'free choices' or 'preferences' to describe consumer behaviour and by presuming same to be rational, we are lured away from thinking about the complete insensitivity of the system, about the systematic and diachronic deprivations and about the undulating playing field.

One is easily justified in believing that the free-market dogma has been playing too dominant a role in policy decisions in higher education. This is evidenced by the demand to design market- or demand-driven courses and programmes, tailored more or less specifically to industrial needs and trendy expectations. Subjects like Classics, which teach general capacities and such normative values as foresight, courage, citizenship, compassion, leadership, honesty, a sense of commitment and duty, et cetera, are seen as peripheral. But, if post-industrial theorists are right, we are already moving away from manufacturing and manual work to a knowledge-based economy where service industry ${ }^{17}$ and non-manual work dominate. This transition from work based on physical strength to mental agility, to knowledge-based services (Bell,1973), requires flexible specialisation, computerised control of production and re-toolable skills. This trend is likely, in the near future, to narrow the academic-vocational divide and to increase the need for curricula that build general capacities rather than vocational specialisms.

Finally, the print and electronic media as well as a wide range of electronic equipment now constitute major sources of information and learning for all classes of people, especially for the youth. This big-scale exposure of individuals to multiple

17 The service industry includes, but is not limited to, such activities as banking, insurance, brokerage, teaching, marketing, public relations, media, computer-related and cultural services. 
sources of information and learning is unprecedented. Baudrillard (1981) may have a point in arguing that we now live in a world which is 'media saturated': a world in which we are bombarded by media and advertising messages through multi-channel television, globalised electronic and cable networks, a profusion of radio stations, newspapers and street billboards. One profound effect of this, Baudrillard argues, is the generation of codes of signification which become rules by which we govern our lives. For example, messages designed to persuade individuals to purchase commodities strongly influence people's priorities in life and affect their attitudes and behaviour. Besides, the presentation of violent and sexually explicit scenes in films and soap operas may not influence everybody; but it may pollute the moral environment and incite a wayward and anarchic few.

The relationship between sex, violence and morality is a theme probably as old as the dawn of human society. Wars or their effects were a common direct experience for adults and the youth in much of antiquity. The vast Roman Empire was built and maintained for centuries by war, to say nothing of the glorification of violence in Roman public entertainments, such as gladiatorial shows. Before Roman imperial hegemony, most Greek city-states were frequently at war. Besides, Greek sympotic vase-paintings are characterised by explicit depictions of sex. And far beyond the bawdiness of Aristophanic comic theatre, ithyphallic processions were spectacular and memorable aspects of annual festivals of Dionysus - the god of wine and fertility. But if frequent wars, bloody gladiatorial sports and the publicity of sexually explicit symbolisms in ancient festivals may have contributed to moral degeneration, the modern print and electronic media reinforce this with their easily accessible and more socially penetrating reach. The problem of our times is whether it is desirable for the handful of people who control our print and electronic media often obsessed with profit or power to have such influence on the moral life of nations?

The question just raised evokes the complex issue of censorship on whether it can be justified. The debate, begun several centuries ago, continues to rack the best brains. Plato, for example, believes that the fine arts primarily appeal to the senses and the desire for pleasure rather than to reason; thus the arts possess a tremendous power for moulding human character, for good or evil. Consequently, in his Republic (books 11 \& lll) he argues for a policy of censorship designed, not in order to eliminate all of the fine arts but to prevent their harmful effects and to promote their good effects with a view to advancing the art of living the rational life. Although Aristotle agrees with Plato that art influences conduct, in his Politics (VIII: 5-7) he thinks that the fine arts have social therapeutic power: far from inciting people to action, they provide a catharsis, an avenue for safely discharging one's excess emotions. Sartre (1948) denies any link between art and morality: morality has to do with conduct; art with aesthetics - a product to be judged by purely aesthetic standards and to be appreciated, not by action, but by contemplation. 
Others, like Dewey (1934), think that the link is reciprocal, based on the common demand for imagination: to be moral requires imaginative effort - a going beyond our individuality - to identify with the ideal of love or right; and art is the imaginative discernment of possibilities that redeems human life from the damnation of routine and boredom. New art, in particular, makes us sensitive to new values, to novel ideas, thereby encouraging moral innovation. Still others, such as the American aesthetician Prall (1957), attempt to subordinate morality to art, by maintaining that all moral values derive from or are species of aesthetic values.

A censorship policy in the absence of a demonstrated link between art and morality is highly questionable. Yet, even if such a link exists, we are confronted with other formidable issues: (1) whether censorship can be justified by the need to preserve moral standards essential for social order and stability; if so whether such censorship will not (2) unjustifiably preserve such standards from critical appraisal and artistic interpretation - a consequence which would (a) arrest moral change and improvement, and/or (b) significantly curtail the right to free speech and thought. And (3) would not censorship centring round essentially vague concepts (e.g., 'obscene') endow law enforcement authorities with an undesirable degree of discretion? In view of these challenges, it seems, unfortunately, that whatever is not directly forbidden by law is permissible or proper.

\section{Modernity, the Family and Community}

Of the many definitions and historical variations of what constitutes a family, I shall mean by 'family' a group of people related by blood, adoption, marriage or a desire for mutual support (Meeks et al., 2005, p. 203; cf. Kirby et al., 1997, pp. 234-250). Different scholars, depending on their conception of the family, have proposed various social functions or roles of the family-from reproduction, sexual satisfaction, rearing of children (Muncie, Wetherell, Dallos, \& Chochrane,1995, pp. 11-12), the provision of economic, social and emotional needs for its members (O'Connell, 1994, p. 1), to the reproduction of the capitalist system (Engels, 1884; Beechey, 1977; Zaretsky, 1977). Whatever conception of family is at stake, modernity has greatly modified the social experience of family members due to many interlocking factors, including the rise or intensity of bureaucracy, the pull of urbanisation, the need to take up long-term residence elsewhere for employment and economic individualism. The effects include a pronounced weakening of the bonds between members of extended families. Even within the nuclear family, a sharp distinction has come to exist between the home and the workplace - the home having become, for most working parent(s), a place for taking a meal or so a day and for sleeping and less a place for close and continuous warm relations of affection and emotional support. Although these changes are not easy to quantify, there is, as a matter of fact, much less interaction and interdependence among members of the 
extended family than was the case in antiquity, when most families lived together in the same house or neighbourhood.

Modernity has also significantly affected community spirit, if we take 'community' to mean an aggregate of human beings characterised by relatively informal relationships between individuals who know each other moderately well and who have certain shared interests, concerns and responsibilities; or, the social interactions and interrelationships beyond the immediate family, as seen, for example, in the typical village situation (cf. Gyekye, 1997, pp. 41-43; Anderson, 1971, Fletcher, 1966). In modernity, bonds between people are based on economic, political, or professional ties more than on kinship; and there are strong tendencies towards individualism, secularism and nuclearisation of the family. ${ }^{18}$ In such societies it is common for the expression 'good neighbours' to mean those who mind their own business rather than those with whom, as in antiquity, one has an easy-going, informal, reciprocally supportive relationship. The educated elite in Africa, as well as African governments, tend to construct residential facilities that look inward to the occupants rather than outward towards neighbours - an increasing individuation of essentially social beings. ${ }^{19}$

Arguably, the nuclearisation of the family facilitates both geographical and social mobility - a useful adaptation to the demands of industrialized economy and society. On the other hand, this general shrinking of the extended family and the disintegration of the community spirit are resulting in less effective kin-related, social-psychological and moral support networks; in less interest in or responsibility for local affairs; in fewer opportunities for co-operative small-group interaction; and in fewer activities that give rise to a sense of personal involvement, belonging and love. The new social reality of 'each for himself/herself' may contribute to a sense of isolation or alienation that may have long-term side effect on our social humanity.

\section{Bureaucracy}

By 'bureaucracy' I shall mean the formal organisation of masses of workers in an effort to control, coordinate and monitor their working activities in order to achieve the specific goals of an organisation or institution. Complex hierarchical bureaucracies did exist in many imperial systems in antiquity: in China, Rome, Byzantium, Mali,

\footnotetext{
18 This general conclusion is not falsified by one or two counter-examples. O'Connell, 1994, p. 10 saw that urbanisation has not led inevitably to a disintegration of the extended family system. In Kenya households are generally larger in urban than in rural areas because of the following: the rising age of first marriage means young adults remain in their parental home for longer periods; economic difficulties hamper couples establishing separate residential units; and individuals who migrate to the cities usually live with other family members.

19 For a discussion on African communitarianism, see Gyekye, 1997, pp. 35-75.
} 
Songhai and Ashanti, to name a few ${ }^{20}$. Unprecedented, however, is the present globalised, techno-bureaucratisation of organisational or institutional work-in schools, churches, private businesses, public agencies, governments, et cetera. Weber notes that bureaucracy replaces decision-making procedures based on habit, custom and tradition with processes of scientific organisation and decision-making. Bureaucracy imparts qualities of order, stability and predictability to and promotes efficiency, procedural and rule-based precision and explicitness in, organisational management and governance structures (cf. Blau, 1963, pp. 1-2; Kirby, 1997, pp. 353-363).

Today, the lives of several million people are bureaucratised, with significant impacts on their personal and family life. Weber feared that the growth of bureaucracy would become a threat to individual freedom: 'the more bureaucracy is dehumanised, the more completely it succeeds in eliminating from official business love, hatred and all purely personal, irrational and emotional elements which escape calculation' (Weber, 1946, pp. 214, 215-216). Weber overstates the air of impersonality that bureaucratic formalism generates. Our common experience is that informal interactions are always present, to various degrees, in bureaucracies. On the other hand, it is true that bureaucracy tends to produce life-conditions that deviate significantly from the work ethic to which our genetic constitution has adapted us: the rigid hierarchy and status differentiation; the routine monotony of job because of specialisation; the absence of opportunity for initiative and creative behaviour, especially for those below executive positions; the rigid formalisation of human relations; and the sedentary fixation - eight or more hours a day spent in or around an office for twenty or thirty odd years in one's working life. These experiences, among others, constrain the tendency of all humans to seek personal involvement, self-esteem, a sense of belonging, excitement, variety in daily experience and regular physical activity alternating with regular periods of relaxation and leisure.

Evidence from biomedical science suggests that the sedentary requirement of the modern bureaucratised life, combined with low levels of physical activity, leads to premature death or the development of cardiovascular diseases, type-2 diabetes, high blood pressure, colon cancer, obesity, depression and anxiety. The same evidence shows that regular physical activity reduces or prevents the risks of developing these conditions and promotes social-psychological well-being - as regular physical activity induces the

20 It is unlikely that these pre-industrial bureaucracies met all of Weber's criteria of a standard case: (1) the distribution of regular activities as fixed official duties; (2) the division of labour by specialised competences; (3) the systematic discipline and control of the official; (4) the government of all operations by a consistent system of abstract rules and the application of such rules to particular cases; (5) the hierarchical organisation of offices; (6) the subjection of an official's official duties to authority; (7) the appointment (not election) of candidates for bureaucratic positions on the basis of technical qualifications; and (8) the bureaucratic position as a career that can be advanced by promotion. See Weber, 1968: 3304. 
norepinephrine and beta-endorphin hormones that promote feelings of wellness (Meeks et al., 2005, pp. 340-343).

\section{Sleep, Rest and Leisure}

Sleep, a state of deep relaxation in which there is little movement or consciousness, helps to restore physical, emotional and mental energy. Rest, a period of relaxation, whether asleep or awake, counteracts physical and mental fatigue and helps us to cope with stress. Inadequate sleep and rest make one prone to accident or mistakes.

In hunter-gatherer societies, adults usually slept or rested as a spontaneous response to the physiological urge to do so and this is consistent with the biological sleepclock of our species (cf. Boyden, 1987, p. 70). In ancient Greece, the daily life of the adult male, especially the educated and wealth elite, involved spending some time in the afternoon in the gymnasium, available in many towns, training, exercising or relaxing (Hibler, 1988). As a culture, modernity has tended to disturb our natural patterns of sleep and rest. It is true that modern science and technology have in many respects advanced our conception and practice of leisure and rest, which now include ways in which individuals and groups express and construct lifestyles through leisure tastes and activities (cf. Kirby et al. 1997, p. 465). For example, listening to live band music or watching a satellite transmission of a major soccer match in a restaurant while eating or drinking is now a way to rest or relax. However, the exhausting daily demands of work for the full-time employee and the general life-conditions in industrialised societies leave little, if any, time for adequately relieving oneself of stress and tension (Hordern, 1976). Besides, although we are told that about eight hours of sleep for adults is good for our health, the conditions of modern life systematically make a certain degree of insomnia the norm. And chronic insomnia is known to affect the immune system. It has also been observed that participation in leisure is still, as in much of antiquity, structured by social class and gender. Now a few professionals, among them fewer women than men, are able to engage in indoor sports on a much larger scale than the mass of working class people. The reasons for the differential include the following. Access to income is required, since, generally, charges are levied even when leisure centres are publicly owned and one may either need a car or pay for transport to get to the centre. Career women who are also mothers tend to have fewer leisure hours because they take up major responsibilities in the running and management of the home; and they may not be encouraged by their male partners to spend their leisure time outside the home on their own (Kirby et al., 1997, p. 363). Without appropriate intervention, liberal democracy and industrial capitalism have a long way to go in delivering significant empowerment of women and their liberation from the age-long burdens of responsibility that limit opportunities for rest and leisure. For all its rigid organisation of society, ancient Sparta promoted, as a matter of policy, leisure, recreation and exercise on equal terms for both men and women. 


\section{The Environment}

Antiquity seems to have been aware that the abuse and pollution of the physical environment was suicidal for mankind; hence the ancestral investment of groves, forests, meadows, water bodies and other vital sections of the ecology with sacredness and sanctity. The suicidal consequence of environmental degradation is captured in the ancient Greek allegory of Erysichthon, the mythical Thessalian king who chopped down the sacred grove of the goddess Demeter in order to build himself a feast-hall. For degrading the environment, Demeter inflicted him with insatiable hunger, driving him to exhaust his riches and, finally, in poverty, to devour his own flesh. The moral of the myth is that our practical inability to distinguish between need and want is a significant factor in the process of our biological and environmental degradation.

Environmental pollution is a serious, well-known side effect of modernity (Passmore 1980; Sauer, 1956, pp. 49-69). Pollution is any change in the air, water, soil, noise level or temperature that has a negative effect on life and health (Meeks et al., 2005, p. 465). For example, the relentless extraction of natural resources results in the increasing loss of the regenerative capacity of the earth, the pollution or destruction of water sources and the reduction or destruction of the main sources of sustenance for millions of rural communities. ${ }^{21}$ This is especially acute in the western part of Ghana, which, for many decades, has been the hub of commercial logging and open-cast mining (cf. Ziem, 2013).

The endless exploitation of varied natural resources, together with the provision of an ever-widening network of supporting services to meet the growing needs and wants of industrial societies, has required the extensive use of machines powered by fossil fuels. The daily combustion of fossil fuels, including emissions from running motor vehicles, is widely known to be a significant source of global energy use and environmental pollution, especially in the Third World. Fossil fuels (e.g., coal, oil, gasoline, natural gas) are formed from plant or animal remains as a result of pressure over several hundred years. When such remains are burnt they produce, among other things, carbon monoxides, ${ }^{22}$ sulphur oxide, ${ }^{23}$ airborne lead, ${ }^{24}$ nitrogen oxides,,${ }^{25}$ and particulates. ${ }^{26}$ Let us look at these pollutants in some detail.

It is common knowledge that prolonged exposure to sulphur oxides damages the cilia $^{27}$ and results in increased likelihood of respiratory diseases such as asthma,

\footnotetext{
21 The loss of the protective cover of the forest affects soil fertility and agricultural productivity; and there is also the reduction of oxygen, of biodiversity (through the destruction of species of plants and animals), and of the sources of medicine. Cf. Nsamenang, 1992, pp. 45-68.

22 An odourless gas whose poison reduces the ability of blood to carry oxygen to the body cells.

23 Sulphur-containing chemicals that irritate the nose, throat, and eyes.

24 Tetraethyl lead added to motor spirit to prevent premature detonation.

25 Nitrogen-containing chemicals that irritate the respiratory system.

26 Tiny particles in the air - soot, ash, dirt, dust, and pollen, etc. - which harm the cilia and travel deep into the lungs to damage the lungs.

27 The hair-like structures in the respiratory system that remove dust and other particles from the air we breathe.
} 
emphysema, bronchitis and lung cancer. For decades, studies have shown that mean concentrations of sulphur oxides in excess of 500 micrograms per cubic metre are associated with high mortality rates (cf. Coffin \& Knelson, 1976); that levels of about 15 micrograms per cubic metre of carbon monoxide are common in industrialised cities; that exposure to levels of 9 to 16 milligrams per cubic metre increases mortality from coronary disease; and that the probability of motor accidents may be higher with greater carbon monoxide exposure, symptoms of which include headaches, dizziness, lassitude, flickering before the eyes, ringing in the ears, nausea, vomiting, difficulty in breathing and apathy (Boyden, 1987, p. 251).

The combination of sulphur oxides and nitrogen oxides with water vapour in the air results in acid rain-rain water or other form of precipitation that has a high acid content. Acid rain destroys plant crops, changes the composition of water in lakes or rivers, causes fish to die and even damages buildings. Further, in the presence of sunlight, water vapour in the air combines with motor vehicle emissions or the smoke and particles from factories to form smog, a threat especially to the elderly and to people who have various respiratory conditions. Sulphur dioxide was the chief component in the notorious London smog that killed 12,000 individuals and made 100,000 sick (Bell et al., 2004). Smog is also harmful to gases such as the ozone - a form of oxygen and a protective layer of the upper atmosphere of the earth that traps the harmful ultra violet (UV) radiation from the sun and prevents it from reaching the earth's surface. We know that too much of UV radiation is harmful to living tissue and is associated with cataracts and other conditions that harm farms and forests (Meeks et al., 2005, pp. 463-467).

Either from the emissions of motor vehicles or from pipes that supply water, lead is especially concentrated in urban areas. An acceptable average is around 2 to 4 micrograms per cubic metre. The lead content of air in modern city streets is commonly up to 10 micrograms per cubic metre but sometimes reaches 25 micrograms (Boyden, 1987, p. 252). City dwellers therefore regularly inhale lead. In most industrialised societies, concentrations of lead in the blood of 10 to 15 micrograms are common. ${ }^{28}$ Even higher levels are found in people who are frequently exposed to the exhaust fume of motor vehicles. The symptoms and signs of lead poisoning are numerous. Epidemiological studies $^{29}$ show that adults who are exposed to a dangerous amount of lead can experience anaemia, nervous system dysfunction, weakness, hypertension, kidney problems, decreased fertility and increased levels of miscarriages, low birth weight and premature deliveries (Voorhis, 2010). Children exposed to high levels of lead show similar

28 Strictly, lead in the blood is measured in micrograms of lead per decilitre of blood (mg/dL).

29 Studies on how diseases spread and are to be controlled. 
symptoms, especially mental dysfunction (Shurke, 2010) because the central nervous system is the body system most sensitive to lead (Meeks et al., 2005, p. 471). ${ }^{30}$

Health hazards caused by high noise levels using modern technology constitute another side effect of industrialisation. A decibel $[\mathrm{dB}]$ is a unit used to measure the loudness of sounds. A noise level of $40 \mathrm{~dB}$ is the acceptable maximum when people are talking. But sounds that measure more than $70 \mathrm{~dB}$ harm the environment, animal and human life. Local increase in noise levels in factories, on busy streets and near airports deviates significantly from the noise levels in the natural or evolutionary environment to which humans are suited. Indeed a few individuals find extreme levels of noise in discotheques, up to $120 \mathrm{~dB}$, enjoyable. But the enjoyable is not necessarily compatible with the healthy: noise levels of $90 \mathrm{~dB}$ will cause a temporary reduction in the acuity of hearing and frequent exposure to such levels over long periods of time produces permanent impairment (Boyden, 1987, p. 253; Meeks et al., 2005, p. 473) ${ }^{31}$ In a busy city street today, the noise level may be up to $100 \mathrm{~dB}$. High noise levels can also affect general health and well-being indirectly, by interrupting other sensory inputs, thereby interfering, for example, with enjoyable conversation or the contemplation of visually beautiful scenery.

In Ghana, as indeed in most of Africa, there are many occasions or events at which excessive levels of continuous noise are generated with instruments of modern technology. These include funerals, festivals, parties, sports, church service, hallweek celebrations in residential universities. Loud and continuous honking is a favourite pastime of drivers across the country. Again in Ghana and, presumably, in many Third World countries, there is little, if any, evidence that relevant state regulatory bodies regularly monitor or measure environmental pollution. This contrasts with what happens in the USA, where the federal Environmental Protection Agency measures air quality in all major cities on a daily basis; many newspapers and TV stations report on current air quality and sometimes advise that it is not healthy to exercise outdoors because of poor air quality; and there are many non-governmental agencies that advocate clean and

30 There is not enough space to talk about indoor air pollution, which takes a toll on our lives more subtly and much more deeply because it is trapped indoors and is, therefore, more concentrated. Indoor pollutants may be in water heaters (which can release the poisonous carbon monoxide), building materials like plywood, other wood products, insulations, cosmetics, upholstery, carpets, and other floor coverings. Meeks et al., p. 468 indicate that various household appliances contain formaldehyde, a colourless gas which, when inhaled, causes shortness of breath, couching, dizziness, eye irritation, headaches, nausea, cancer, asthma, and more. Well-known among the harmful gases, and a leading cause of the thinning of the ozone layer, are the group called chlorofluorocarbons (or CFCs). Because these are easy to compress and expand, they are used as propellants in aerosol sprays, and as coolants in air conditioners, insulations, and refrigerators. Because enclosures trap and concentrate pollutants, the glass houses springing up all over Accra and other tropical cities, with limited ventilation and built more for their aesthetic appeal than for promoting health, raise serious questions about the practical value of our education system.

31 Several home appliances, e.g., blenders and vacuum cleaners, create a lot of noise in excess of $80 \mathrm{~dB}$. 
healthy environment, educate the public on environmental issues and organise projects to improve the environment (Meek et al., 2005, p. 466).

\section{Diet}

In the sense of (a) what we eat and (b) how much we eat, diet is one of the most significant ways in which modernity has affected and continues to affect our biology. Nutritionists and pathologists agree that the Mediterranean diet - a triad of cereals, olive and vine, supported by a high intake of fruits, nuts and vegetables - is generally healthier than the diets of the affluent West (Garnsey, 1999, p. 1). Indeed, the Mediterranean diet has seen foreign intrusions of maize, potatoes, tomatoes and sugar; it has also seen some corrosion, with the traditional triad being transformed by Western food technology (Garnsey, 1999, pp. 12-13). The story is similar across cultures whose foods and eating habits have been transformed by Western food technology. In some cases, this has resulted in significant deviations from thresholds most suitable for humans. Let us start with the quantity of foods.

Hunter-gatherers ate only when they were hungry (cf. Boyden, 1979, p. 256). In contrast, we moderns tend to overeat these days, for the following reasons, among others. First, there is ready availability or affordability of food, including junk food, euphemistically called 'fast-food.' Second, there is the regular practice of removing the fibre, which is relatively non-digestible, from foods of grain or plant origin. Without the fibre, more food energy than is appropriate for our health can be consumed before one feels full. Third is snacking (eating between meals) out of personal or workplace-induced boredom, loneliness, anxiety, depression or other conditions. Fourth, regular meal times, dictated largely by working conditions, compel us to have three major meals a day. Indeed, the meal-time experience can be positive, if it brings the family together to the table. But the demands on our time as a result of pressures of work and other obligations permit only rare occurrences of such experiences. The fifth reason why we tend to overeat is palatability. In the natural environment of antiquity, there was little conscious distinction between palatability and nutritiousness: in their habitat, animals and early peoples find palatable those food stuffs of survival value to them-foods to which their tastes, digestive systems and metabolism are suited through evolution. Pawpaw, sugar cane, mango, guava, banana, et cetera, satisfied the natural desire for sweetness, while meat served the natural desire for salt.

In modernity there is some disconnect between palatability and nutritiousness: modern food science and technology create irresistible sights, tastes and smells that tend to break down the restraints of appetite. Over-consumption leads to obesity, a body whose weight is $20 \%$ or more than is desirable; and this increases the risk of heart disease and certain types of cancer (Meeks et al., 2005, p. 315). Obesity threatens to become the leading health problem in the $21^{\text {st }}$ century. The UN's World Health Organisation in its 
2003 Report describes obesity as an 'escalating global epidemic' in many parts of the world that is spreading into the developing world. In another research, close to $40 \%$ of Americans are obese. In the 2001 Report of the Centres for Disease Control and Prevention (CDC), an estimated 300,000 annual deaths in the USA occur from causes related to obesity. Most diet-related diseases result from excess fat ${ }^{32}$ and calories. ${ }^{33}$ Research shows that the average daily intake of fatty substances (of animal origin) is considerably higher in industrialised societies than in earlier phases of civilisation. Besides, the fat content of industrially reared animals is considerably higher than that of animals left to graze naturally on grassland (Boyden, 1987, p. 263). Moreover, a higher proportion of the fat in the industrially reared animals is saturated, that is, turns solid at room temperature. Its over-consumption contributes to high levels of blood cholesterol and is a source of various heart diseases and cancers. As the McDonalds, the Kentucky Fried Chickens and countless miniature local varieties of these are dotted at all points of human traffic in African cities and even villages, they exploit the limited time budgets of individuals, providing foods that often contain more calories and fat than the body needs at a time. This also comes with the risk of food poisoning. According to the 2000 Report of the CDC, an estimated 76 million cases of food-borne illness occur each year in the USA, of which there are about 325,000 hospitalisations and about 25,000 deaths (Meeks et al., 2005, p. 306). In those developing countries where there are no equivalents of CDCs or where the state agencies that regulate and report on food safety and health are ineffective and where the general culture is illiterate in food chemistry and scientific standards of health, both the production and risk of contracting various food-borne diseases are likely to be very high.

Additives constitute another problem in the diets of most people in industrial societies (Millstone, 1984). An additive is any substance deliberately added to food to preserve it or to improve its flavour, colour, texture, taste or appearance. The difference between additives and ingredients is sometimes difficult to draw. An example is table salt. But generally additives are chemical compounds, many of them synthetic. As additives, preservatives protect foods from decomposition; and a significant percentage of the world's harvest could be lost to the activities of microbial, fungal and animal pests without preservatives; but that cannot be said for most other additives. Take the apparently harmless table salt. Thanks to modern science and technology, salt is cheap and available in unlimited quantities. Meek et al. (2005, p. 286) report that most people can get adequate sodium ${ }^{34}$ in their diet without adding extra salt to their food. Indeed, it has been calculated that one slice of a conventional loaf of bread provides sufficient salt

32 A nutrient that provides energy and helps the body to store and use vitamins.

33 A unit of energy produced by food used by the body.

34 Sodium regulates and maintains the balance of fluids in the body. 
to satisfy an individual's physiological needs for one day. Yet, we add salt to our vegetables, soups, sauces and so on; and it is contained in most canned and processed foods. The available evidence suggests that the majority of people consume 10 to 15 times more than is necessary for their metabolic requirements, a clear deviation from the evolutionary life-conditions of the human species (Boyden, 1987, p. 264). It is now established that when patients with hypertension are put on a salt-free diet, their blood pressure [the force of blood against the artery walls] drops; and that the consumption of salt at levels above those found in natural foods leads to high blood pressure. ${ }^{35}$ Increasing blood pressure after the age of 25 used to be considered normal in industrialised societies, until it was discovered that in certain non-industrialised societies (Papua New Guinea and some islands in the South Pacific) where people did not (at the time of research) add salt to their food, blood pressure decreases slightly as the individuals grow older after the age of about 25 (Boyden, 1987, p. 265). If excess salt can do this to us, what about the other additives?

Another issue that is important but cannot be dealt with adequately here for lack of space is the increasing chemicalisation of the soil and the farm for the sake of quantitative yield. This practice contaminates the food right from the start. Market gardening in and around the city of Accra, which uses highly polluted sewage water, belongs to this class of 'organic contamination.' A survey carried between 2007 and 2008 revealed that vegetables consumed in Accra had more than a dozen chemicals, all above tolerable percentages. In a report of the survey, Mr. George Ortsin, Country Programme Coordinator of the Small Grants Programme of the UNDP/Global Environment Facility (GEF), revealed at a media consultative workshop organised by the Environmental Protection Agency (EPA) in Accra that samples of vegetables on sale collected from various markets across Accra showed that most contained toxic chemicals that exceeded $2000 \%$ and that the least recorded was 500\% ('Most vegetables in Accra found contaminated-Survey,' 2012). Slowly but progressively, nutritional science is demonstrating that there is no diet more conducive to human health and wellbeing than the diet to which our species is genetically adapted through evolution, that is, the varied diet of the typical hunter-gatherer: the fruits, fresh vegetables, nuts, roots, berries, some cooked lean meat (cf. Meeks et al., 2005, pp. 283-320).

\section{Conclusion}

In this paper, I have tried to highlight some of the unintended side effects of Western industrial culture which threaten our long-term ecological and biological sustainability. The suggestion here is that 'modern' does not necessarily and always mean

35 Blood pressure of 140/90 mm Hg or greater for an extended time. 
'better' and that a conscious and creative adaptation of some life-conditions and lifestyles in antiquity could offer a viable alternative for promoting our biology and ecology. Alternatively, certain policy controls are required to correct or limit aspects of modern life-conditions and lifestyles that significantly deviate from those which enhance rather than threaten our biology and ecology. 


\section{References}

Anderson, M. (1971). The sociology of the family. Harmondsworth, UK: Penguin.

Aristotle, S. (1995). Politics. (E. Barker, Trans.; R. F. Stalley, Rev. with introduction and notes). Oxford, UK: Oxford University Press.

Baier, K. (1958). The moral point of view. New York, NY: Random House.

Baudrillard, J. (1981). For a critique of the political economy of the sign. St Louis, MO: Telos.

Beechey, V. (1977). Some notes on female wage labour in capitalist production. Capital and Class, 3, 45-66.

Bell, M. L., Davis, D. L., \& Fletcher, T. (2004). A retrospective assessment of mortality from the London smog episode of 1952: The role of influenza and pollution. Environ Health Perspect, 112 (1), 6-8.

Bidwai, P. (2009). The convergence of fundamentalisms and new political closures: What next in the struggle for pluralism? Development Dialogue, 52, 23-44.

Blau, P. M. (1963). The dynamics of bureaucracy. Chicago, IL: University of Chicago Press.

Boyden, S. (1987). Western civilization in biological perspective. Oxford, UK: Clarendon Press.

Coffin, D. L., \& Knelson, J. H. (1976). Effects of sulphur dioxide and sulfate aerosol particles on human health. Ambio, 5 (5-6), 239-242.

Dewey, J. (1934). Art as experience. New York, NY: Putman.

Durant, W. (1953). The pleasures of philosophy. New York, NY: Simon \& Schuster.

Engels, F. (1884). Origins of the family, private property and the state. London, UK: Lawrence and Wishart. (Repr. 1972).

Fletcher, R. (1966). The family and marriage in Britain. Harmondsworth, UK: Penguin.

Foley, R. (1987). Another unique species: Patterns in human evolutionary ecology. Cheltenham, UK: Longman.

Garnsey, P. (1999). Food and society in classical antiquity. Cambridge, UK: Cambridge University Press.

Gilles, R. (2009). Pluralism in economics teaching. Development Dialogue, 52, 43-77.

Gyekye, K. (1997). Tradition and modernity: Philosophical reflections on the African Experience. Oxford, UK: Oxford University Press.

Harrison, P. (1981). Inside the Third World: The anatomy of poverty ( $2^{\text {nd }}$ ed.). Harmondsworth: Penguin Books.

Hayek, von F. (1944). Road to serfdom. Chicago, IL: University of Chicago Press.

Hibler, R.W. (1988). Life and learning in ancient Athens. Lanham, MD: University of America Press.

Hordern, A. (1976). Tranquillity denied: Stress and its impact today. Sidney, Australia: Rigby. Huxley, T. H. \& Huxley, J. (1947). Evolution and ethics 1893-1943. London: Pilot.

Kirby, M. et al. (1997). Sociology: In perspective. Oxford, UK: Heinemann Educational Publishers.

Leiss, W. (1978). The limits to satisfaction: An essay on the problem of needs and commodities. London, UK: Marion Boyars. 
Max-Neef, M. A. (2009). From knowledge to understanding: Navigations and returns. Development Dialogue, 52, 15-21.

Meeks, L., Heit, P., \& Page, R. (2005). Comprehensive school health education (4 ${ }^{\text {th }} \mathrm{ed}$.). New York, NY: McGraw-Hill.

Millstone, E. (1984). Food additives: A technology out of control? New Scientist, 104, 20-24. Most vegetables in Accra found contaminated-Survey (2012, November). General News. Retrieved from www.ghanabusinessnews.com

Muncie, J., Wetherell, M., Dallos, R., \& Cochrane, A. (Eds.). (1995). Understanding the family. London, UK: Sage.

Nsamenang, A. B. (1992). Human development in cultural context: A Third World perspective. Newbury Park, CA: Sage.

O'Connell, H. (1994). Women and family. London: Zed Books.

Passmore, J. (1980). Man's responsibility for nature: Ecological problems and Western traditions. London, UK: Duckworth.

Plato (1997). Republic. In J. M. Cooper (Ed.), Plato: Complete works. Indianapolis, IN: Hackett Publishing Company.

Prall, D. W. (1957). Aesthetic judgment. New York, NY: Thomas Y. Crowell Company.

Roszak, T. (1976). Ecology and mysticism: The rhapsodic intellect. In J. R. Burr \& M. Goldinger (Eds.), Philosophy and contemporary issues (pp. 463-469). New York, NY : Macmillan Publishing Co., Inc.

Sartre, J. P. (1948). The psychology of imagination. London, UK: Routledge. (Repr. 2001).

Sauer, C. O. (1956). The agency of man on earth. In W. L. Thomas (Ed.),Man's role in changing the face of the earth, 1, (pp. 49-69). Chicago, IL: University of Chicago Press.

Shurke, J. (2010, November 14). Adult blood lead levels. SHARP. Washington State Department of Labour.

Thomas, W. L. Jr. (Ed.). (1956). Man's role in changing the face of the earth. Chicago, IL: University of Chicago Press

Voorhis, N. (2008, January14). Lead-elevated blood levels in children. Virginia Department of Health.

Weber, M. (1921). The theory of social and economic organization. (A. M. Henderson \& T. Parsons, Trans.). New York, NY: Harvard University Press.

Weber, M. (1946). Essays in sociology. (H. H. Gerth \& C. W. Mills, Trans.). New York, NY: Oxford University Press.

Wolbring, G. (2009). What next for the human species? Human performance enhancement, ableism and pluralism. Development Dialogue, 52, 141-161.

Zaretsky, E. (1976). Capitalism: The family and personal life. London, UK: Pluto.

Ziem, J. (2013, April 30). Ghanaians must protect fresh water resources. Retrieved from http://www.ghanaweb.com. Accessed 4/30/2013 at 4:00 pm 